\title{
Judas Maccabaeus and the Roman Republic: Greek Political Vocabulary in 1 Macc 8:1
}

\author{
JANUSZ NAWROT \\ Adam Mickiewicz University in Poznań \\ jannaw@amu.edu.pl, ORCID: 0000-0002-2498-5081
}

\begin{abstract}
The literary genius of the author of the First Book of the Maccabees shows in his ability to use the diplomatic realities of politics in the account of Judas Maccabeus, who strives to sign a pact with the Roman republic. The terms to describe politics have their own long history that dates back to the Greek world before Rome reached its prime. The use of these terms to represent Judas' policy towards Rome in 1 Macc 8:1 was not an artificial ingenuity of the author but rather his intentional borrowing. By utilising terms from the spheres of politics and diplomacy, the author was capable of matching them with the everlasting value of the message contained in the inspired text. This message was extremely important for the author. Thus he was able to harmonise elements of world politics with God's action. The Lord would use everything made by humans to exercise His will toward His own people.
\end{abstract}

Keywords: Hellenistic world, Roman republic, politics and diplomacy, The First Book of the Maccabees

The presentation of the vocabulary typical of diplomatic milieu, which the inspired author included in the description of the actions taken by the leader of the Jewish uprising in 1 Macc 8 , is intended to convince the reader that the treaty between Judas Maccabaeus and the Roman Republic actually took place. The manner in which the hagiographer presents the events and describes Judas' actions proves his expertise in the realities of international politics at the time.

The purpose of this article is to look at individual terms contained in 1 Macc 8:1 in comparison to other texts by various authors of Hellenic, Hellenistic and Roman antiquity. ${ }^{1}$ Of special value are the notes of the historians using the same words in the description of various political, military and diplomatic efforts. First, we will try to establish how selected, characteristic terms used in international politics in

1 The extrabiblical writers referred to by the author of the article created their works in all three epochs of antiquity and at the turn of the millennium. The time of the reign of Alexander the Great over the years 336-323 BC is traditionally seen as the boundary between the first and the second epoch. By contrast, the end of Hellenism was followed by the victory of the Roman Republic over Egypt in the Battle of Actium in 31 BC, Burn, Hellenistic Art, 11. During the Roman period, however, the year $27 \mathrm{BC}$ should be adopted as the dividing line, when the actual reign of Octavian Augustus, as emperor of Rome, began. This year is considered to have been the end of the Republic and the beginning of the Empire, Ziółkowski, Historia Rzymu, 353-358. 
the second half of the second century $\mathrm{BC}$ function in the titular verse and throughout the First Book of Maccabees. Of course, it should be borne in mind that the terms listed in the article were not used in Greek only in a political and military context because they can also be found in many other types of texts. Nevertheless, when such a context appears, the authors also use them there, and - as it turns out - most often in a technical sense, to highlight specific circumstances accompanying the alliances which were established.

Preferential treatment will be given to the accounts of historians of the olden days, whose writing style is the closest to the text of the First Book of Maccabees. Thus, I will resort mainly to the accounts by Herodotus account (ca. 485-421 BC), Thucydides (ca. 470- 404 BC), Xenophon (ca. 430-355 BC), Polybius (ca. 200-118 BC), Diodorus Siculus (ca. 80-20 BC) or Pausanias (110-180 AD). Most of these accounts either witnessed the establishment of tradition and diplomatic vocabulary or, as in the case of Pausanias, demonstrates its durability and stability for many centuries to follow. ${ }^{2}$ Nevertheless, wherever the similarity of situation, purpose or mode of action appear with greater clarity, quotes from other ancient authors will also be presented. The structure of the article shows the terms in question first in the inspired book with the meaning assigned to it by the hagiographer, then - if available in the rest of the Scriptures and other texts of ancient Greek literature. The political context of the quoted statements will then be presented each time so that the reader will be able to capture this precise connotation of a given word.

\title{
1 Macc 8:1
}

\author{
"And Ioudas heard the name of the Romans (P $\omega \mu \alpha i \omega v)$, \\ that they were powerful in strength

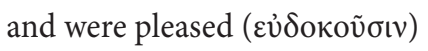

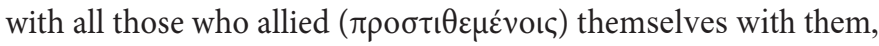

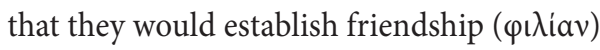 \\ with all those who come ( $\pi \rho \circ \sigma \dot{\varepsilon} \lambda \theta \omega \sigma v)$ to them \\ and that they are powerful in strength" (NETS).
}

In the broader context of v. 1-16, the inspired author lists the achievements of the Roman Republic known to him, dating back to the Gallic wars (v. 2), military campaigns in Spain (v. 3), battles with the Macedonian kings Philip and Perseus (v. 5) and especially with the ruler of the Seleucid empire, Antiochus III the Great (v. 6-8)

2 It would be appropriate to include Josephus Flavius (37-94 AD) in this respectable group, but due to the borrowings from the texts of the First Book of Maccabees, which he made in his Antiquities of the Jews I omit him in this discussion. Moreover, the amount of these borrowings from the inspired text is so considerable that it would disproportionately extend this article. 
and the wars in Greece (v. 9). This brief overview of the Republic's accomplishments was presented in the form of information that Judas might have obtained from the spreading news, perhaps some written documents, personal or diplomatic contacts not mentioned in the book. The hagiographer underlines this point in a general manner when he says that "Judas heard the name of the Romans" (v. 1). In other words: he learned the history of their deeds, especially about their victories and conquests, and it convinced him that he should use them as an inspiration in the fight for the independence of his own nation.

\section{a) $\varepsilon \dot{\delta} \delta \circ \kappa \varepsilon \dot{\omega}$}

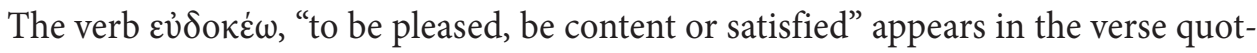

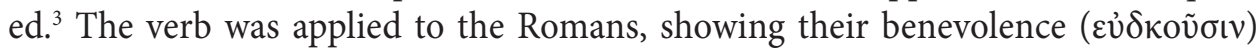
towards all who wanted to make an alliance with them. Throughout the book, the hagiographer uses the verb in the same sense as liking based on the expected benefits, as shown in the following list of inspired texts.

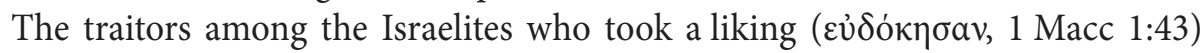
to the cult imposed by Antiochus IV Epiphanes were described in a severely negative sense because thanks participation in this cult, they were able to gain greater social acceptance of the Greeks living in Jerusalem. The same applies to the speech of the traitors who came to Antiochus and asked him to intervene against the insurgents. The envoys of the followers of Hellenization remind the king of their will-

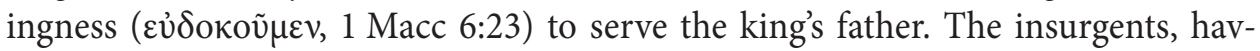

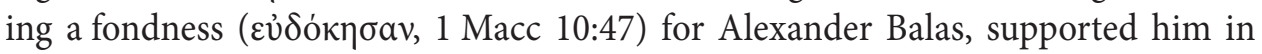
his war against Demetrius I Soter because they considered the benefits of a having peace treaty with him, which they deemed to be more credible than the one with his

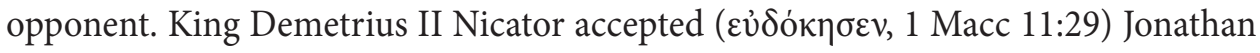
Maccabee's gift of 3,000 talents of silver in exchange for granting him rights to govern three districts in Palestine. Expecting great benefits from Simon's reign over the Jews,

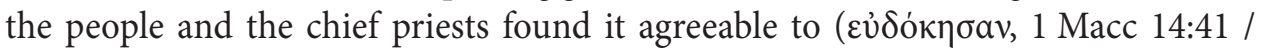

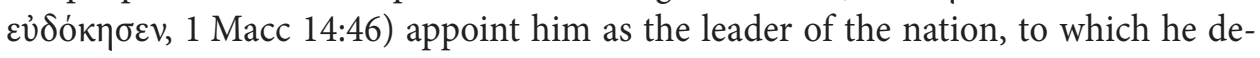

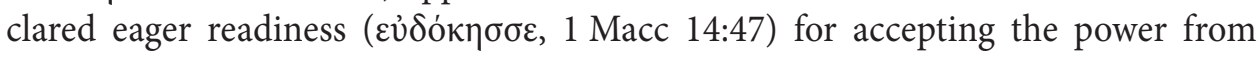
the people. The hagiographer uses this verb in a specific context of social relations and, in some cases, even strictly diplomatic ones. The rest of the Scriptures also use this verb to denote a liking based on the benefits that can be gained through the attitude of the other party. ${ }^{4}$

Montanari, The Brill Dictionary of Ancient Greek, ad loc.

4 Similarly, in among others Gen 33:10; Lev 26:34,41; 2 Sam 22:20; 1 Chr 29:3,23; 2 Chr 10:7; Jdt 15:10; Ps 101:15 (LXX); Sir 15:17; Hag 1:8; 2 Cor 5:8; 12:10. 
The term has a similar meaning also in extrabiblical literature, ${ }^{5}$ especially in the context of a result of conducted negotiations. ${ }^{6}$ Polybius offers an excellent commentary on Judas' actions with regard to the Romans in The Histories III, 31: 5-8:

For how can anyone when wronged himself or when his country is wronged find helpmates and allies; how can he, when desirous of acquiring some possession or initiating some project, stir to action those whose co-operation he wishes; how, finally, if he is con-

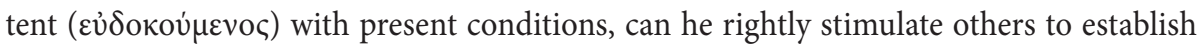
his own convictions and maintain things as they are, if he knows nothing at all of the past history of those he would influence? For all men are given to adapt themselves to the present and assume a character suited to the times, so that from their words and actions it is difficult to judge of the principles of each, and in many cases the truth is quite overcast. But men's past actions, bringing to bear the test of actual fact, indicate truly the principles and opinions of each, and show us where we may look for gratitude, kindness, and help, and where for the reverse (LCL 137, 78-79).

In the quoted fragment, the historian points out that any political action undertaken is motivated by the desire to make alliances for three main reasons:

a) a personal threat or a threat to one's own country,

b) desire to secure support from allies in planned operations, ${ }^{7}$

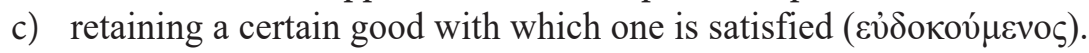

However, in all these cases, it is necessary to seek prior information about the one with whom necessary arrangements are to be made. Such information stems from the knowledge of the previous achievements and actions of those to whom the interested party turns. That is exactly what Judas did when he found out about the successes of the Romans, which the hagiographer lists (vv. 1-16). In accordance with Polybius' description, the facts from the past became the most important, giving the warranty of effectiveness and political benefit for the plans of the insurgence leader. Such information provided him with a guarantee of the value of the deal he was going to propose to them. It is also worth mentioning that if the case of Judas belongs to the first of the reasons mentioned in Histories, the Republic was definitely satisfied with the third reason, being the desire to maintain the situation in which it currently found itself, reaching the peak of its military power. Concluding

5 Among others Polybius, Histories I, 8.4; 78.8; 83.8; II, 38.7; 49.3; VI, 6.11; VII, 4.5; Diodorus Siculus, Library of History XI, 47.2; XVII, 47.2.

$6 \quad$ Polybius, The Histories II, 12.3; V, 55.10; 107.5; XIV, 2.11; XV, 8.8; Diodorus Siculus, Library of Histo$r y \mathrm{XV}, 16.1$; Dionysius of Halicarnassus, Roman Antiquities II, 38.5; III, 13.1.

7 The sentence: "when he wants to get something and be the first to start the action" does not lead directly to the conclusion about the anticipated confrontation with enemies, but the generality of this statement and the preceding statement about the danger threatening someone or his country do not exclude this interpretation, making it justified. 
an agreement with Judas will allow Rome to maintain or even strengthen the hitherto held position on the political chessboard of the eastern Mediterranean basin. Therefore, despite an offer from such an insignificant ally, the Republic was inter-

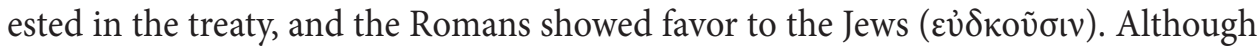
the initiative of its conclusion comes from the insurgents, not the Republic, it does not contradict the written record of Polybius, because political activity in this third case is understood in a general sense: the policy of Judas fits into the direction of the Republic's operations aiming to strengthen its presence in the Middle East.

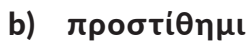

In the discussed verse 1 there also appears a participle $\pi \rho \circ \sigma \tau \theta \varepsilon \mu \varepsilon$ vo with a pronoun in dative, which translates as: "adjoined to, associated with, adhered to, joined the side of (side with)," litical and military alliance. The verb $\pi \rho \circ \tau i \theta \eta \mu \mathrm{can}$ be found in 1 Macc 2:43 with the same meaning in the note about joining ( $\pi \rho 0 \sigma \varepsilon \tau \dot{\varepsilon} \theta \eta \sigma a v)$ the insurgents by all of those who did not wish to agree to the restrictions of Antiochus IV Epiphanes against

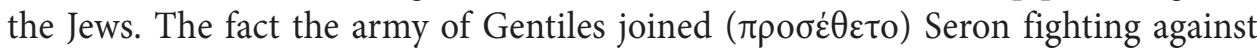
Judas Maccabaeus is mentioned in 1 Macc 3:15. The same situation can be observed

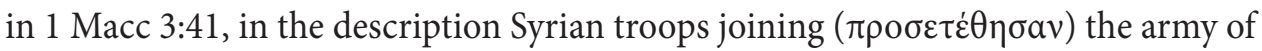
Lysias. According to 1 Macc 9:1, King Demetrius, having learned of Nicanor's death, agreed ( $\pi \rho \circ \varepsilon \dot{\varepsilon} \theta \varepsilon \tau)$ to send Bacchides' army for the second time with the ungodly high priest Alcimus against Judas. ${ }^{9}$ In other books of the Bible, the verb appears, for example, in Exod 1:10, in the speech of the ruler of Egypt, suspecting the Hebrews of the possibility of joining ( $\pi \rho 0 \sigma \tau \varepsilon \theta \dot{\eta} \sigma o v \tau \alpha)$ the enemy in a possible armed conflict with other countries. The close, though non-political, context of the alliance $(\pi \rho \circ \sigma \theta \tilde{\eta} \sigma \theta \varepsilon)$ of the Israelites with the Gentiles, worthy of stigmatization on account of their departure from the faith, is also noted in the text of Jos 23:12. The same verb appears in the note about the approach ( $\pi \rho \circ \delta \dot{\varepsilon} \theta \eta \kappa \varepsilon v)$ of envoys sent by Jephthah to the king of the Ammonites in Judg 11:14. In the fight against the Benjamites, the Is-

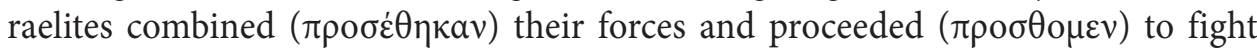
after consulting the Lord (Judg 20:22-23,28). Humiliated in skirmishes, the Philistines did not proceed (ov $\pi \rho \circ \sigma \varepsilon \dot{\varepsilon} \theta v \tau$ ) to fight in order to attack the land of Israel (1 Sam 7:13). The Philistine army entered ( $\pi \rho \circ \sigma \varepsilon \dot{\varepsilon} \varepsilon \tau 0)$ war with Saul, suffering a bitter defeat in a battle with David's army (1 Sam 19:8). Later they proceeded

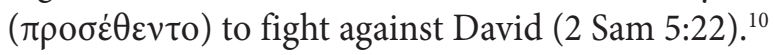

8 Montanari, The Brill Dictionary of Ancient Greek, ad loc.

9 Several further statements by the hagiographer contain the same military and political context of the verb in 1 Macc 9:72; 11:1. In 10:30,38 and 11:4, there is reference to adjoining new lands to Judea as a result of negotiations between the insurgents and the Seleucid side.

10 A similar context of proceeding to execute a task can be found, among others, in $2 \mathrm{Kgs} 1: 11,13$; $1 \mathrm{Chr}$ 14:13; $2 \mathrm{Chr} 15: 9$. In the sense of discontinuing a task, cf. 2 Kgs 6:23; $24: 7$. 
Similarly, in the diplomacy functioning in the world of Gentiles, combining forces by signing treaties is a normal political move, as in the case of the Macedonian King Philip II, wishing to become an ally of Athens. The scene of persuading the Athenian aristocracy to make a pact with Philip is described by Aeschines in Aeschines in On the Embassy 2:17:

Finally Democrates of Aphidna went before the senate and persuaded them to summon Aristodemus. One of the senators was Demosthenes, my accuser! Aristodemus appeared before them, reported Philip's great friendliness toward the city, and added this besides,

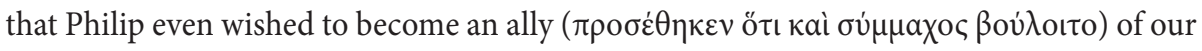
state. This he said not only before the senate, but also at an assembly of the people. Here again Demosthenes spoke no word in opposition, but even moved that a crown be conferred on Aristodemus (LCL 106, 173).

In the year $348 \mathrm{BC}$, on behalf of Philip, envoys arrived in Athens from Euboea, who informed the authorities of the city, that the Macedonian ruler wanted to end the war and make peace with Athens. The negotiations on the release of the Athenian prisoners, held captive by the Macedonians, were conducted by an Athenian actor and Philip's friend, Aristodemos. Before addressing the assembly, he passed a mes-

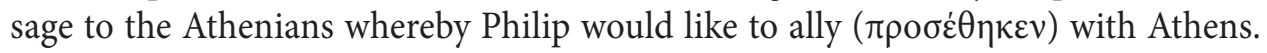
However, they rejected his proposal resolving to continue the war and trying to draw other Greek city-states into it. The measures taken by the Athenians did not bring the expected result as none of the cities joined them. ${ }^{11}$ The political connotation of $\pi \rho о \tau i \theta \eta \mu$ does not stem directly from the meaning of the word itself because it is only a notification from Aristodemos to the city's elders about Philip's intention. However, it shows his clear intention to enter into an arrangement with the Athenians, and that is why this verb can be integrated into the sphere of diplomacy.

In The Persian Wars I, 53 Herodotus mentions a question asked by the ruler of Lydia, Croesus, to the Delphic Oracle concerning the possibility of his army joining allied forces in the war against the Persians:

The Lydians who were to bring these gifts to the temples were charged by Croesus to inquire of the oracles, "Shall Croesus send an army against the Persians: and shall he take

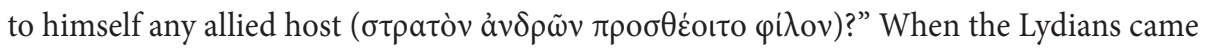
to the places whither they were sent, they made present of the offerings, and inquired of the oracles, in these words: "Croesus, king of Lydia and other nations, seeing that he deems that here are the only true places of divination among men, endows you with such gifts as your wisdom merits. And now he would ask you, if he shall send an army against

11 Ellis, Philip II and Macedonian Imperialism, 106. An interesting study on the relationship between Macedonian rulers and Greek cities was developed by Billows, Kings and Colonists, 56-80. 


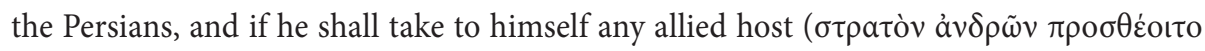

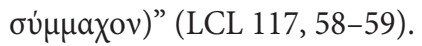

The oracles, having received gifts, unanimously announced to him that if he attacked the Persians, a great state would collapse. ${ }^{12}$ The ruler being convinced that they were referring to them, decided to go on an expedition, following the advice of the oracle to win over the most eminent Greeks. The ambiguity of the oracle was wellknown to many who had consulted it. That is what happened in this case, too. This "great state" was, as a matter of fact, Lydia, which the Persian ruler, Cyrus the Great, attacked in the winter of 547 BC, capturing Sardis, the capital of Lydia, after a 14-day siege of the city. ${ }^{13}$

In the further part of The Persian Wars, Herodotus reports on the subsequent endeavors of Croesus still before he joined the war with Persia. The Lydian ruler sent his representatives to Sparta to present his offer of an alliance with this city (I, 69):

They came, and said: "Croesus, King of Lydia and other nations, has sent us with this message: "Lacedaemonians! the god has declared that I should make the Greek my friend ( $\varphi$ i $\lambda$ ov $\pi \rho \circ \sigma \theta \dot{\varepsilon} \sigma \theta a \mathrm{l}$ ); now, therefore, as I learn that you are the leaders of Hellas, I do so

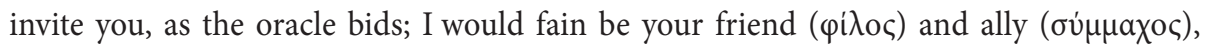
without deceit or guile" (LCL 117, 82-85).

Convinced of the bravery and prudence of the Spartans, the king of Lydia, rolling in gold, offered the largest city of the Corinthian peninsula a war deal to persuade them to march against Persia by offering rich gifts. ${ }^{14}$ Thus, he informed the Spartans of the predictions of the oracle, which they received with appreciation, having heard of this divine prophecy before and understanding it in the same way as Croesus. Therefore, they readily agreed to the proposal and - as Herodotus writes - "made

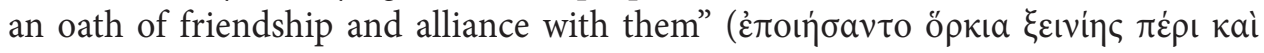

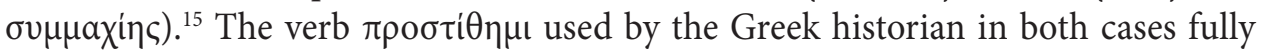
corresponds to the political-military meaning given to it by the author of the First Book of Maccabees.

Xenophon, in turn, mentions the betrayal of the Persian general Ariaeus and his troops, who were previously allies of the Greek troops, and their passing under the command of Artaxerxes (Anabasis III, 2.2):

12 Croesus' relationship with the Delphic oracles is analyzed, among others, by Parke, "Croesus and Delphi," 209-232 and Thonemann, "Croesus and the Oracle," 152-167.

13 Tschirschnitz, Dzieje ludów biblijnych, 115. On the manner in which Herodotus describes the operation of the Delphic oracle, Fontenrose, The Delphic Oracle, 111-115.

14 Such a campaign took place leading to the fall of Croesus, Leloux, "La bataille de (la) Ptérie," 407-416 and Evans, "What Happened to Croesus?," 34-40.

15 More about the Spartan-Lydian alliance, Leloux, "L'alliance lydo-spartiate," 274-275. 
Fellow soldiers, painful indeed is our present situation, seeing that we are robbed of such generals and captains and soldiers, and, besides, that Ariaeus and his men, who were for-

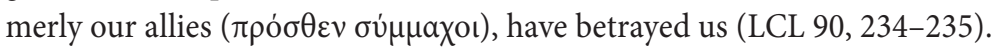

The above sentence is an excerpt from a speech by a Spartan, a certain Cheirosophos, to a convened gathering of Greek soldiers fighting the Persians. The gathering was convened after the execution of the most important commanders of the Greek troops, including strategists and the so-called lochagoi, being the counterpart of today's rank of captain. ${ }^{16}$ The role of Ariaeus was to betray the Greeks who remained loyal to Cyrus. After he was killed in the Battle of Cunaxa in $401 \mathrm{BC}$, Ariaeus changed his strategy and surrendered to Arsaces, the enemy of Cyrus, who assumed the name of Artaxerxes II from 404 BC, as he was his older brother. Together with Tissaphernes, the main Persian strategist in the conspiracy against the Greeks, they invited approx. 20 of their unarmed commanders and 200 soldiers to a friendly meeting during which they captured and murdered nearly all of them. ${ }^{17}$ The phrase $\pi \rho$ ó $\sigma \theta \varepsilon v$

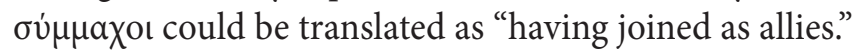

One testimony to the use of this verb in the context of Rome's operations is found in the work of Pausanias, Description of Greece IV, 31.1:

Augustus gave Thuria into the possession of the Lacedaemonians of Sparta. For when Augustus was emperor of the Romans, Antony, himself a Roman, made war upon him and was joined ( $\pi \rho \circ \sigma \varepsilon \dot{\varepsilon} \varepsilon v \tau$ ) by the Messenians and the rest of the Greeks, because the Lacedaemonians were on the side of Augustus (LCL 188, 340-341).

Thouria is a town in ancient Messenia, situated in the eastern part of the Messenian Plain, on the Pamisos River, approximately $1.6 \mathrm{~km}$ from the coast. After the subjugation of Messenia, it was one of the main cities of the Lacedaemonian perioeci. ${ }^{18}$ Already in 146 BC, as a result of its defeat during the Achaean War, Messenia, along with other parts of Greece, fell directly under Roman rule. Like other cities that had previously fought the Romans, it was deprived of its walls and armaments, as well as

16 Cf. Aelianus Tacticus, Taktikē theōria 5, 1; Arrian of Nicomedia, Technē Taktikē 5, 6; Asclepiodotus Tacticus, Taktikē 1, 2.

17 Xenophon, Anabasis II, 5:30-32.

18 They formed a social layer and group of people who were not citizens of Laconia and Messenia, regions controlled by Sparta. They lived most often in coastal and mountainous areas, Cartledge, The Spartans, 67. 
its own authorities. ${ }^{19}$ As Pausanias writes, the city shared the fate of Mark Antony's allies. ${ }^{20}$ It became part of the province of Laconia, which supported Octavian. ${ }^{21}$

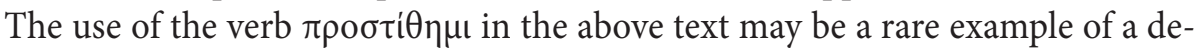
scription of the allied operations of the Roman Republic. Nevertheless, Pausanias also used this verb, most likely in the same sense as the author of 1 Macc 8:1. This is especially visible in the fact that in both cases the initiative was shown by parties who were not the main players on the political arena of the time. In 1 Macc it was Judas and the insurgents, and in the case of the war between Octavian Augustus and Mark Antony, it was the Greeks of the individual city-states who picked a side in the dispute.

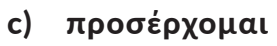

The term which the hagiographer also uses in the context of diplomatic activities

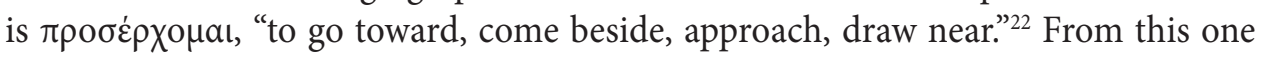
can infer the meaning of "entering into a deal," a description of joining and forming a pact with a common political goal in mind. It seems to be the only use in this sense in the First Book of Maccabees. It may come close to the meaning of the term in $2: 16$ in the description of the decisions of the unfaithful Israelites who "came closer" $(\pi \rho \circ \sigma \tilde{\eta} \lambda \theta 0 v)$ to the Gentiles, and thus accepted the emergence of a foreign cult in their land, counting on specific benefits of material or social nature. It is not, however, an issue of some special arrangement between dissenters and the royal administration. The strictly cult-related connotation is maintained by this verb in

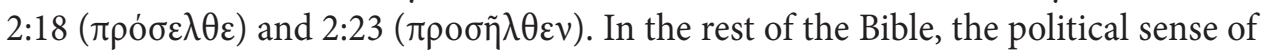
the verb is absent.

However, such a sense can be found in the account of Diodorus Siculus, who in his Library of History XI, 29.1 mentions the agreement between the Athenians and the Spartans in the face of the danger of war with Persia, despite defeating the Persians at the Battle of Salamis in 480 BC:

When Mardonius and his army had returned to Thebes, the Greeks gathered in congress

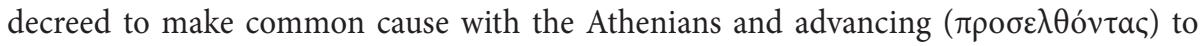
Plataea in a body, to fight to a finish for liberty, and also to make a vow to the gods that, if they were victorious, the Greeks would unite in celebrating the Festival of Liberty on that day and would hold the games of the Festival in Plataea (LCL 375, 200-203).

\footnotetext{
19 Wipszycka - Bravo, Historia starożytnych Greków, 243-245; Pawlak, Rzymski Peloponez, 75, 213.

20 In his fight against Octavian and the defeat of Antony at the Battle of Actium in $31 \mathrm{BC}$, in the last war of the Roman Republic.

21 Even two centuries earlier, after the Battle of Magnesia in BC 190, some Greek cities: Lampsacus, Smyrna, Alexandria-Troas, the cities of Eolis and Ionia, sided with the Republic against Antiochus III the Great, who had lost control over them, as reported by Polybius, The Histories XXI, 14.2.

22 Montanari, The Brill Dictionary of Ancient Greek, ad loc.
} 
After the defeat of the Persian army by the Greeks at the Battle of Salamis, the Persian ruler, Xerxes, withdrew his troops to Asia, leaving only selected troops in Greece under the command of Mardonius. He first tried to persuade the Athenians themselves to make peace with Persia disregarding other Greek city-states in return for assistance in rebuilding the city. It was intended to break the unity of the Greeks in the face of the Persian threat, especially along the Athens - Sparta line. After rejecting this offer, Mardonius headed for Athens, captured it a second time, and destroyed it again in mid-July $479 \mathrm{BC} .{ }^{23}$ Upon learning that the Peloponnesian army was approaching Athens, Mardonius withdrew to Thebes fearing a potential defeat in the mountainous terrain of Attica. The united forces of the Greeks were commanded by the Spartan regent, Pausanias. The two armies met at Plataea, where the Greeks won a crushing victory. When losing the battle, Mardonius himself most likely died in combat. ${ }^{24}$ Diodorus' text mentions an important event before the battle, which was the gathering of the Peloponnesian Greeks deciding to support their compatriots in the war with the Persians, although it was probably a support forced by the danger of Athens concluding peace with the Persian invaders. To this end Sparta, which had remained passive so far, decided to act in order not to prevent the disruption of the Pan-Hellenic community. The decision to formally make a pact between Athens and Sparta, reinforced by the oath to the gods, which resulted in the commemoration of the expected victory with common games in Plataea, proves both political and topographical significance of the word $\pi \rho \circ \sigma \varepsilon$ exoua. ${ }^{25}$ This verb acquires the same meaning in the First Book of Maccabees.

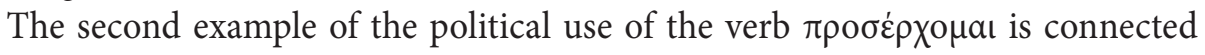
with Thucydides and The History of Peloponnesian War I, 75:

Considering, then, Lacedaemonians, the zeal and sagacity of judgment which we displayed at that time, do we deserve to be regarded with this excessive jealousy by the Hellenes just on account of the empire we possess? And indeed we did not acquire this empire by force, but only after you had refused to continue to oppose what was left of the barbarian forces, and the allies came to us ( $\pi \rho 0 \sigma \varepsilon \lambda \theta \dot{v} v \tau \omega \nu \tau \tilde{\omega} \nu \xi u \mu \mu \alpha \dot{\alpha} \chi \omega \nu)$ and of their own accord asked us to assume the leadership (LCL 108, 126-127).

It is an excerpt from the speech of Athenian envoys before the Lacedaemonian gathering in Sparta in the beginning of the Second Peloponnesian War (431-404 BC), an account of which was written by Thucydides, who was both an Athenian strategist and a historical writer. The battles were waged between the Peloponnesian

23 Herodotus, The Persian Wars IX, 4.

24 Ziółkowski, Historia powszechna, 436.

25 This obligation is described in detail by, among others, Cartledge, After Thermopylae, 12-40. 
League, led by Sparta, and the Delian League, led by Athens. ${ }^{26}$ The story takes place almost 50 years after the successful defense of independence in wars with Persia, but skirmishes still continued here and there. The general reason was the fear of the growing power of Athens, which did not even hide their imperial appetite and eagerness to rule the entire Hellenic world. Sparta's indecisive politics facilitated this situation, as Sparta, contrary to Athens with its expanding influence, was preoccupied with its own affairs after the end of the Persian wars. ${ }^{27}$ The Athenian envoys staying in Sparta for purposes other than political ones - tried to oppose the accusatory speeches of the openly hostile Corinthian envoys who had lost some of their colonies to Athens. ${ }^{28}$ Therefore, applying various kinds of diplomatic pressure, the Corinthians tried to talk both Sparta and the symmachia led by it, into entering the war with the Athenian competitor. Under the influence of their allies, Sparta and the entire Peloponnesian League stated that Athens had broken the truce of $446 \mathrm{BC}$.

The representatives of Athens began their speech by recalling the times of the Persian wars, in which it was Athens that played the most important role, as Sparta made a decision to withdraw from them after achieving its own goals. Athenians' valiance rescued the Peloponnese from destruction too, and in their battles with the Persians, they demonstrated three most important factors: the largest number of ships, the most competent leader, namely Themistocles, and the greatest zeal among all the combatants. Attitude and dedication of such a kind allowed the rest of the Greeks, including the Spartans, to fight against a larger opponent. This is the reason why Athens now claims the right to lead all Greek cities, since many other allied cities of that country had rushed to Athens to beg for their leadership before. Thus, it did not stem from violence, but is somehow a natural result of the events and the history of the city that faced the Persian danger the most bravely.

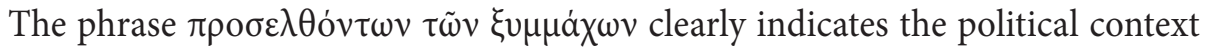
behind the actions of various Greek cities, which aimed to establish a treaty with Athens, as it was in the First Book of Maccabees.

Xenophon in his work Anabasis (IV, 4.5-6) writes about meeting Tiribazus, a deputy governor of Western Armenia and a king's friend, who came to the meeting of Greek troops with a proposal of an arrangement for the duration of the Greeks' passage across the territory under his control:

He rode up to the Greeks with a body of horsemen, and sending forward an interpreter, said that he wished to confer with their commanders. The generals decided to hear what he

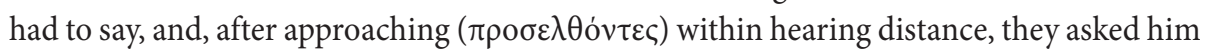

26 The study about the author of the work was undertaken, among others, by Cawkwell, Thucydides and the Peloponnesian War, 1-19. The description of the conflict, presented in Thucydides' eight-volume work, is generally regarded as classical and considered one of the earliest scientific works in history.

27 Kagan, The Outbreak of the Peloponnesian War, 31-74.

28 Thucydides, History of the Peloponnesian War, 11-28; Tritle, The Peloponnesian War, 3-5. 
what he wanted. He replied that he wished to conclude a treaty with these conditions, that he on his side would not harm the Greeks, and that they should not burn the houses, but might take all the provisions they needed. This proposition was accepted by the generals, and they concluded a treaty on these terms (LCL 90, 326-327).

The story takes place during the retreat of the Greek troops hired by Cyrus the Younger from Lydia, Phrygia and Cappadocia to fight against the elder brother and ruler of Persia, Artaxerxes II. When Cyrus was killed in the Battle of Cunaxa, the Greeks, having no reason to fight, decided to return to their homeland right after the betrayal of Ariaeus and Tissaphernes and the murder of their commanders, as it was mentioned earlier. ${ }^{29}$ The text of Anabasis IV, 4 describes difficult conditions of the Greek march, weakened by earlier fights with the valiant Carduchian people (Kurds), and haunted by bands robbing pack horses and stripping soldiers who were dying of fatigue, hunger, cold, and blindness caused by snow. ${ }^{30}$ After crossing the Kurdish mountains, the Greeks finally came to the Armenian Upland, and stopped by the small Teleboas (Karasu) river, where they warmed up by the fire and found accommodation upon entering some villages. Living in Armenian villages abundant in food, the exhausted Greeks managed to have a rest and boost their health and morale, which fortunately facilitated their further journey, due to the agreement

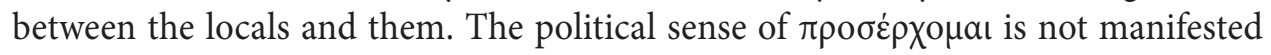
directly, but through an explicit intention of the need to conclude a specific agreement, ${ }^{31}$ although according to the conditions described by Xenophon it did not have the rank a treaty, as the author of the First Book of Maccabees emphasized, but more like an oral agreement. Meanwhile, the condition for its validity is its observance by both parties.

Finally, two examples given by Polybius, who reports the following in The Histories II, 11.11:

Many embassies met them, among them one from the Parthini offering unconditional surrender. They admitted this tribe to their friendship as well as ( $\pi \rho \circ \sigma \varepsilon \lambda \eta \lambda v \theta$ ó $\alpha a \varsigma)$ the Atintanes, and advanced towards Issa which was also being besieged by the Illyrians (LCL 128, 290-293).

29 Xenophon, Anabasis III, 2.2.

30 The Greek historian gives the daily length of troop marches, calculated at 10 to 15 of the so-called parasangs, i.e., a distance of approx. 55-80 km, which, under conditions of immense fatigue, was a really impressive distance (Anabasis IV, 4.3).

31 The verb $\sigma \pi \varepsilon \dot{\varepsilon} \delta \omega \omega$ as used here means "the establishment of a treaty through pouring out a liquid sacrifice," which Thucydides sometimes mentions, Peloponnesian War III, 111; IV, 46, cf. Bailly, Dictionnaire grec-français, 1776. 
This fragment of the Greek historian's work mentions the times when the Roman Republic successfully developed its policy of successive conquests of countries around Italy, although in this case it was not a strictly imperial policy, but more of a disciplinary one for its wayward neighbor, namely Illyria. This country included the lands of the southern part of the eastern Adriatic coast and desired conquests under the rule of Teuta, widow of Agron, the ruler of the country, and regent for her son, Pinnes, who had not come of age yet. First, she began looting merchant ships in the Adriatic Sea and, moreover, won several important battles with the Epireans and the inhabitants of Kerkira, Apollonia and Epidamnos. This caused concerns in the Roman Senate, which declared war on Illyria twice: the first time in 229-228 BC, and the second time over the years 220-219 BC. Polybius' account concerns the first of those wars. ${ }^{32}$ Two hundred Roman ships, commanded by Consul Gnaeus Fulvius Centulamus, sailed to Kerkira and captured the city. A little later, the soldiers of the Republic reached Apollonia, meeting there the troops of the second consul, Lucius Postumius Albinus, which numbered 22,000 foot soldiers and 2,000 horsemen. The people of Apollonia treated the Romans as saviors and put themselves under the protection of Rome. Then Roman troops headed for Epidamnus. After the besieging Illyrians fled, the inhabitants of the city also decided to submit to Rome. The Parthini and Atintanes peoples followed the suit. As the Romans moved towards Illyria, they conquered the Ardiaei people, the most important ethnic group among the Illyrians. After these events, the consuls moved to Issa, besieging by their armies. The Romans managed to conquer several more Illyrian cities. The typically political

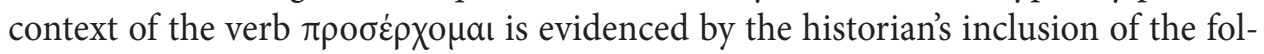
lowing phrases in the same verse of the story: $\sigma v \mu \mu \xi \dot{\xi} \dot{\alpha} \tau \omega \nu \delta \grave{\varepsilon} \pi \rho \varepsilon \sigma \beta \varepsilon v \tau \tilde{\omega} v$, "envoys

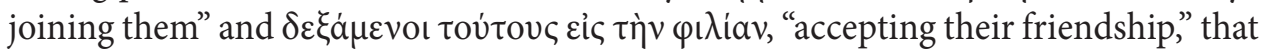
is to say, establishing a political treaty with them. However, we do not discuss these phrases because the author of the First Book of Maccabees does not include them.

In book IV, 26.8, the Greek historian writes:

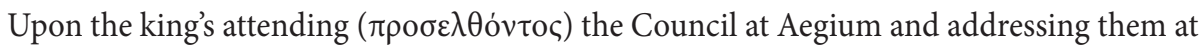
length, they received his speech favourably and renewed with Philip in person their friendly relations with the kings, his ancestors (LCL 137, 400-401).

Aegium became the central gathering place for representatives of the Hellenic League, also known as Symmachia, which included: the Achaean League, Macedonia, Boeotia, Acarnania, Epirus and Messenia. They entered into a cooperation pact against the Aetolian League, Sparta and Elis. The conflict of interest turned

32 To see a study of this period of the Roman Republic's policy towards Illyria, cf. Dzino, Illyricum in Roman Politics, 44-60. 
into the so-called social war which broke out in $220 \mathrm{BC}$ and lasted for three years. ${ }^{33}$ In that year, the troops of the Aetolian League, wishing to counteract the strengthening of Symmachia, attacked the enemy lands, plundering and destroying them. Unwilling to comply with the protests and orders to withdraw to their lands, they were the cause of the declaration of war by Philip V of Macedon and the other members of Symmachia in Aegium in the summer of 220 BC. ${ }^{34}$ The Macedonian king was interested in war as a means of strengthening his country's influence in all of Greece and ultimately subjugating it to himself, therefore the other countries, except for Achaia and Acarnania, were in no hurry to help him. ${ }^{35}$ With the rise of Lycurgus in 219 BC, Sparta joined the Aetolian League. After the wars lost by the Achaean League that year, Philip joined the fight the following year and after successful raids against Sparta he managed to contain the pressure of the Aetolian army. In an unstable campaign of $217 \mathrm{BC}$, amidst revolts of soldiers dissatisfied with their pay and the unfulfilled expectations of allies thirsting for more spoils, Philip abandoned his further campaign against Aetolia, ${ }^{36}$ this time focusing on the Roman Republic, whose dominance on the Greek scene was ever increasing. ${ }^{37}$ So, he brokered peace in Naupactus in 217 BC, guaranteeing that the parties would retain their current

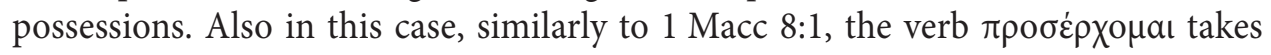
on a political connotation due to the obvious willingness of the parties concerned

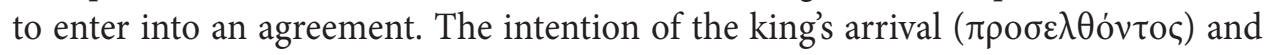
addressing the Council of the League was to bring another political alliance to pass on this particular military issue.

\section{d) Pwraĩos - piגia}

We will combine the last of the terms presented, because each of them separately appears very often in the political and diplomatic context. On the subject of $\varphi i \lambda i \alpha$, mainly in conjunction with $\sigma v \mu \mu \alpha \chi$ ia, "military alliance, allies, allied forces," ${ }^{38}$ several large scholarly works have been written, analyzing both expressions together as perhaps the most typical example of political language present in the accounts of ancient historians. ${ }^{39}$ In order to avoid the necessity of quoting a large number of extra-biblical texts, we will concentrate only on the combination of both of the above terms.

33 An in-depth analysis of the events related to the war was presented by Fine, "The Background of the Social War," 129-165.

34 The circumstances of the outbreak of the conflict are described in Grainger, The League of the Aitolians, 244-296.

35 Walbank, Philip V of Macedon, 24-67.

36 Scholten, The Politics of Plunder, 200-228.

37 Waterfield, Taken at the Flood, 62-79.

38 Montanari, The Brill Dictionary of Ancient Greek, ad loc.

39 As an example, it is worth mentioning highly valuable, though older, studies Matthaei, "On the Classification of Roman Allies," 182-204; Heuss, Amicitia; Brunt, "Amicitia," 1-20 and Cursi, "International Relationships," 186-195. 
This will allow for confirming the inspired author's awareness of the principles of friendship preferred by the Roman Republic in a political context. In the First Book of Maccabees, the term $\varphi i \lambda$ ía functions only in a political and diplomatic context in relations between different states. And so, a friendship is made between the Jews and the Seleucid empire $(10: 20,23,26)$, between the Jews and Rome $(8: 17 ; 12: 1,3,8 ; 10: 16$; $14: 18,22 ; 15: 17)$, Rome and other countries (8:11) as well as the Seleucids and Ptolemaic dynasty in Egypt (10:54). Similarly, in 2 Macc 4:11 such a political friendship is formed between the Jews and Rome. However, in the rest of the books of the Bible, this political dimension of friendship does not exist.

Appian of Alexandria, writing his Roman History, in book IV of Civil Wars (9.69), noted the following:

You cite friendship for the Romans ( $\varphi \imath \lambda i a v \tau \varepsilon$ 'P $\omega \mu$ aiorc), but you have no pity for those on the list of proscribed who are sentenced to death without trial and confiscation of their property. You pretend that you want to hear from the senate, which is the victim of this situation, and no longer able to defend itself, but the senate has already answered you before, when it decreed that all the people in the east should protect Brutus and myself (LCL $534,308-309)$.

This is an excerpt from the speech of praetor Gaius Cassius Longinus to the Rhodians who acted unfair towards him and his brother-in-law, Marcus Junius Brutus, refusing to aid in the fight against Publius Cornelius Dolabella, the Roman consul. In 43 BC Cassius campaigned against Dolabella in Laodicea and then against the people of Rhodes, whom he accused of being ungrateful to him and favoring his competitor. In a battle at the entrance to Myndos, in the summer of 43 B.C., in the Aegean Sea, he defeated the fleet of Rhodes who had previously refused to pay a contribution. When he landed on the island, he plundered the city and killed $50 \mathrm{em}$ inent citizens, taking over all the gold he was able to grasp. ${ }^{40}$ It was part of a strategic plan to fight the allies of the Second Triumvirate, after the murder of Julius Caesar, a plot in which Cassius also participated. ${ }^{41}$ The quoted fragment of the speech to the Rhodians is his response to the message they sent in order to calm the situation and avoid the destruction of the city, which, however, failed because Cassius' claims were justified. On the other hand, most probably, his objective was probably to loot the city in the first place. ${ }^{42}$ In spite of the difficult position of the Republic, which was under pressure from young Octavian in the fight against the Senate, he carried out his plan. ${ }^{43}$ The last blow to the Republic was the victory of Antony over Cassius and

\footnotetext{
40 Warry, Warfare in the Classical World, 177.

41 Defeated at the Battle of Philippi together with Brutus in $42 \mathrm{BC}$, he committed premature suicide, cf. Sabin - van Wees - Whitby, The Cambridge History of Greek and Roman Warfare, 137.

42 Wipszycka - Bravo, Historia starożytnych Greków, 543-544.

43 Ziółkowski, Historia powszechna, 766.
} 
Brutus, the last of its supporters, in the Battle of Philippi in 42 BC. ${ }^{44}$ The expression

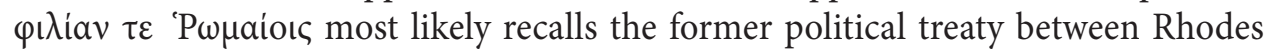
and Rome, according to which islanders were supposed to assist the Republic in its fight against the Seleucid king Antiochus III the Great. ${ }^{45}$

In turn, Polybius, in The Histories III, 24.1-3.8-9, presents it in the following way:

v. 1-3: At a later date they made another treaty, in which the Carthaginians include Tyre and Utica, and mention, in addition to the Fair Promontory, Mastia and Tarseum as points beyond which the Romans may not either make marauding expeditions, or trade, or found cities. This treaty is more or less as follows: "There is to be friendship ( $\varphi \imath \lambda i \alpha v)$ on the fol-

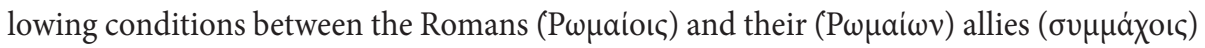
and the Carthaginians, Tyrians, and the people of Utica and their respective allies" (LCL $137,62-63)$.

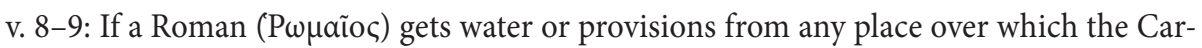
thaginians rule, he shall not use these provisions to wrong any member of a people with

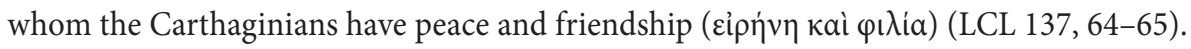

Controversies concerning the treaty between Rome and Carthage are significant and difficult to resolve definitively. The researchers believe that Polybius took a fair amount of liberty in interpreting the events prior to the Punic Wars only on the basis of second-hand sources, namely the stories, and not direct access to the document. ${ }^{46}$ Therefore, the text quoted above is in all likelihood part of a trade treaty of $306 \mathrm{BC}$, described by Titus Livius (The History of Rome IX, 43). ${ }^{47}$ Between Rome and Carthage, a treaty was concluded, under which Italy was excluded from the economic domination of Carthage, just as Sicily remained outside the commercial interests of Rome. ${ }^{48}$ The term $\varphi i \lambda i a$ has a political context, although it concerns the sphere of trade, which is structured through negotiations, contrary to most political contexts in the military domain or international relations, which also the text of the First Book of Maccabees treats about.

\section{Conclusion}

Summarizing the above analysis, it is pertinent to note the purposefulness of the terms used in the quoted verse of the First Book of Maccabees. The inspired

\footnotetext{
44 Bringmann, Historia Republiki Rzymskiej, 365-368.

45 Gruen, "Rome and Rhodes," 58.

46 Cary, "A Forgotten Treaty," 67-68.

47 The two earlier ones were concluded in 348 and 343, and the last one in 279 BC.

48 Details of the issue in question are given by Serrati, "Neptune's Altars," 113-134.
} 
writer demonstrated his very good understanding of the diplomatic realities of his time to describe the decision of the Maccabean insurgence leader wishing to establish diplomatic relations with the Romans. On the other hand, the selected concepts of politics have their own long history, forged a few centuries earlier, in the Greek world, before Rome had reached the peak of its power as a republic by influencing the system of powers, particularly in the eastern Mediterranean. The examples quoted demonstrate that the application of the terms specific to the Greek world in relation to the actions of Rome in 1 Macc 8:1 was not an artificial literary invention of the author, but a borrowing from the realities of the contemporaneous political world in which they functioned on a daily basis.

It is also possible to speak of the literary genius of the hagiographer who, using these concepts in the field of politics and diplomacy, was able to fit them perfectly in the enduring value of the message of his work. The knowledge of the reality shown was used by him to describe a certain stage of the Jewish revolt in the inspired text, the message of which was definitely the most important to him. He was thus able to align very well what constitutes one of the elements of the world politics with God's actions, using everything that humans create in order to impose their will over their own people. It is also evident that not only the terminology used in the texts of the First Book of Maccabees leads to certain theological conclusions but also the manner of Judas Maccabeus' actions - a typically secular one - shows the way of departure from obedience to God's law on the part of Judas himself and the participants of the insurgence following their leader.

Translated by Grzegorz Knyś

\section{Bibliography}

Aeschines, Speeches (trans. C.D. Adams) (Loeb Classical Library 106; Cambridge, MA: Harvard University Press 1919).

Appian, Roman History. V. Civil Wars, Books 3-4 (trans. B. McGing) (Loeb Classical Library 543; Cambridge, MA: Harvard University Press 2020).

Bailly, A., Dictionnaire grec-français, 26 ed. (Paris: Hachette 1963).

Billows, R.A., Kings and Colonists. Aspects of Macedonian Imperialism (Leiden - New York Köln: Brill 1995).

Bringmann, K., Historia Republiki Rzymskiej. Od początów do czasów Augusta (Poznań: Wydawnictwo Poznańskie 2010).

Brunt, P.A., "'Amicitia' in the Late Roman Republic," Proceedings of the Cambridge Philological Society 11 (1965) 1-20.

Burn, L., Hellenistic Art. From Alexander the Great to Augustus (Los Angeles, CA: Getty 2004). Cartledge, P., After Thermopylae. The Oath of Plataea and the End of the Graeco-Persian Wars (Oxford: Oxford University Press 2013). 
Cartledge, P., The Spartans. An Epic History (London: Macmillan 2003).

Cary, M., "A Forgotten Treaty between Rome and Carthage," Journal of Roman Studies 9 (1919) 67-77.

Cawkwell, G., Thucydides and the Peloponnesian War (London - New York: Routhledge 2006). Cursi, M.F., "International Relationships in the Ancient World," Meditationes de iure et historia. Essays in Honour of Laurens Winkel (Pretoria: Unissa Press 2014) I, 186-195.

Diodorus Siculus, Library of History. IV. Books 9-12.40 (trans. C.H. Oldfather) (Loeb Classical Library 375; Cambridge, MA: Harvard University Press 1946).

Dzino, D., Illyricum in Roman Politics, 229 BC-AD 68 (Cambridge: Cambridge University Press 2010).

Ellis, J.R., Philip II and Macedonian Imperialism (Princeton, NJ: Princeton University Press 2016). Evans, J.A.S., "What Happened to Croesus?"” The Classical Journal 74/1 (1978) 34-40.

Fine, J.V.A., "The Background of the Social War of 220-217 B.C.," The American Journal of Philology 61 (1940) 129-165.

Fontenrose, J., The Delphic Oracle. Its Responses and Operations with a Catalogue of Responses (Berkeley, CA - Los Angeles, CA: University of California Press 1978).

Grainger, J.D., The League of the Aitolians (Leiden: Brill 1999).

Gruen, E.S., "Rome and Rhodes in the Second Century B.C.: A Historiographical Inquiry," The Classical Quarterly 25/1 (1975) 58-81.

Herodotus, The Persian Wars. I. Books 1-2 (trans. A.D. Godley) (Loeb Classical Library 117; Cambridge, MA: Harvard University Press 1920).

Heuss, A., Amicitia. Untersuchungen zu den rechtlichen Grundlagen der römischen Aussenpolitik (Leipzig: Schulze 1933).

Kagan, D., The Outbreak of the Peloponnesian War (Ithaca, NY - London: Cornell University Press 1989).

Leloux, K., "La bataille de (la) Ptérie. La Lydie face à la Perse (ca. 547 av. J.-C.)," Actes du 9e Congrès de l'Association des Cercles Francophones d'Histoire et d'Archéologie de Belgique (Liège, 23-26 août 2012) (Liège: Institut Archéologique Liégeois 2017) III.2, 407-416.

Leloux, K., "Lalliance lydo-spartiate," Ktèma 39 (2014) 271-288.

Matthaei, L.E., “On the Classification of Roman Allies," The Classical Quarterly 1 (1907) 182-204. Montanari, F., The Brill Dictionary of Ancient Greek (Leiden - Boston, MA: Brill 2015).

Parke, H.W., "Croesus and Delphi," Greek, Roman and Byzantine Studies 25/3 (1984) 209-232.

Pausanias, Description of Greece. II. Books 3-5 (Laconia, Messina, Elis 1) (trans. W.H.S. Jones - H.A. Ormerod) (Loeb Classical Library 188; Cambridge, MA: Harvard University Press 1926).

Pawlak, M., Rzymski Peloponez. Greckie elity polityczne wobec cesarstwa (Kraków: Towarzystwo Wydawnicze "Historia Iagellonica" 2011).

Polybius, The Histories. I. Book 1-2 (trans. W.R. Paton - F.W. Walbank - Ch. Habicht) (Loeb Classical Library 128; Cambridge, MA: Harvard University Press 2010).

Polybius, The Histories. II. Books 3-4 (trans. W.R. Paton - F.W. Walbank - Ch. Habicht) (Loeb Classical Library 137; Cambridge, MA: Harvard University Press 2010).

Sabin, P.A.G. - van Wees, H. - Whitby, M. (red.), The Cambridge History of Greek and Roman Warfare. II. Rome from the late Republic to the Late Empire (Cambridge - New York: Cambridge University Press 2007). 
Scholten, J.B., The Politics of Plunder. Aitolians and Their Koinon in the Early Hellenistic Era (Berkeley, CA - Los Angeles, CA - London: University of California Press 2000).

Serrati, J., "Neptune's Altars: The Treaties between Rome and Carthage," Classical Quarterly 56/1 (2006) 113-134.

Thonemann, P., "Croesus and the Oracle," Journal of Hellenistic Studies 136 (2016) 152-167.

Thorley, J., Athenian Democracy (London - New York: Routledge 1996).

Thucydides, History of the Peloponnesian War. I. Books 1-2 (trans. C.F. Smith) (Loeb Classical Library 108; Cambridge, MA: Harvard University Press 1919).

Tritle, L.A., The Peloponnesian War (Westport, CT - London: Greenwood Press 2004).

Tschirschnitz, A., Dzieje ludów biblijnych (Warszawa: Sadren i S-ka 1994).

Tukidydes, Wojna peloponeska (trans. K. Kumaniecki) (Warszawa: Wydawnictwo Czytelnik 1988).

Walbank, F.W., Philip V of Macedon (Cambridge: Cambridge University Press 1940).

Warry, J.G., Warfare in the Classical World (New York: Barnes \& Noble 2000).

Waterfield, R., Taken at the Flood. The Roman Conquest of Greece (Oxford: Oxford University Press 2017).

Wipszycka, E. - Bravo, B., Historia starożytnych Greków (Warszawa: Wydawnictwo Uniwersytetu Warszawskiego 2010) III.

Xenophon, Anabasis (trans. C.L. Brownson - J. Dillery) (Loeb Classical Library 90; Cambridge, MA: Harvard University Press 1998).

Ziółkowski, A., Historia powszechna. Starożytność (Warszawa: Wydawnictwo Naukowe PWN 2011).

Ziółkowski, A., Historia Rzymu (Poznań: Poznańskie Towarzystwo Przyjaciół Nauk 2008). 
